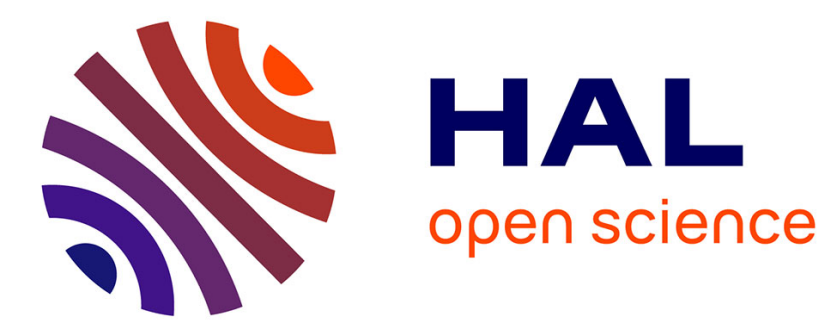

\title{
Impact of temperature variation on penetration test parameters in compacted soils
}

\author{
H. Eslami, S. Rosin-Paumier, Adolf Abdallah, F. Masrouri
}

\section{To cite this version:}

H. Eslami, S. Rosin-Paumier, Adolf Abdallah, F. Masrouri. Impact of temperature variation on penetration test parameters in compacted soils. European Journal of Environmental and Civil Engineering, 2013, 19 (5), pp.628 - 648. 10.1080/19648189.2014.960952 . hal-01913247

\section{HAL Id: hal-01913247 \\ https://hal.science/hal-01913247}

Submitted on 6 Nov 2018

HAL is a multi-disciplinary open access archive for the deposit and dissemination of scientific research documents, whether they are published or not. The documents may come from teaching and research institutions in France or abroad, or from public or private research centers.
L'archive ouverte pluridisciplinaire HAL, est destinée au dépôt et à la diffusion de documents scientifiques de niveau recherche, publiés ou non, émanant des établissements d'enseignement et de recherche français ou étrangers, des laboratoires publics ou privés. 
Impact of temperature variation on penetration test parameters in compacted soils

Eslami, H. ${ }^{\mathrm{a}, \mathrm{b}}$, Rosin-Paumier, S. ${ }^{\mathrm{a}}$, Abdallah, A. ${ }^{\mathrm{a}}$, Masrouri, F. ${ }^{\mathrm{a}}$

${ }^{a}$ LEMTA (CNRS, UMR 7563), Université de Lorraine, Vandoeuvre-lès-Nancy, France ;

${ }^{b}$ ESITC de Metz, Metz, France

*Corresponding author: hossein.eslami@univ-lorraine.fr

sandrine.rosin@univ-lorraine.fr

adel.abdallah@univ-lorraine.fr

farimah.masrouri@univ-lorraine.fr

Postal address: LEMTA, Bâtiment E, 2 rue du Doyen Marcel Roubault, TSA 70605, 54518 Vandoeuvre-lès-Nancy, France 
Impact of temperature variation on penetration test parameters in compacted soils

ABSTRACT: In geotechnical engineering, the proper design of thermo-active geostructures (piles, foundations, etc.) and deep waste storage disposals requires a better understanding of the thermo-hydro-mechanical behaviour of natural and compacted soils. Important mechanical parameters of the soils such as the cone resistance $\left(q_{c}\right)$ and the friction sleeve resistance $\left(f_{s}\right)$ are usually obtained by penetrometric in situ tests. In the present study, penetration tests, adapted from the static penetration method, were conducted in laboratory using a minipenetrometer, to characterise compacted samples. The objective was to examine and quantify the influence of temperature changes on penetration parameters of two different compacted soils. Samples of an illitic material and a kaolinite-sand mixture compacted at different initial water contents and dry densities were subjected to a range of temperatures from 1 to $70{ }^{\circ} \mathrm{C}$. The cone resistance $\left(q_{c}\right)$ and the friction sleeve resistance $\left(f_{s}\right)$ were measured.

Obtained results showed that the particle size, the density and the nature of compacted soils have an important effect on the penetration test parameters. For illitic samples, we obtained significant variation of the cone resistance and friction sleeve resistance with temperature on the dry side of the compaction curve, while limited changes were observed on the wet side. For the kaolinitesand mixture, the temperature effect on these two parameters was negligible.

Keywords: Laboratory tests; Penetrometer; Temperature; Compacted soils; Illite; Kaolinite-Sand mixture.

\section{Introduction}

In geotechnical engineering the effect of temperature should be clearly studied particularly for applications such as the storage of nuclear waste, the remediation of contaminated sites and the burying of high-voltage cables and thermo-active 
geostructures. These geostructures are used to provide sustainable heating and cooling by thermal exchange between buildings and the ground through liquids that flow through closed-loop circulation systems integrated into the geostructures. These systems use the subsurface soil as a heating or cooling source for the buildings. Geostructures may be piles, diaphragm walls, tunnel linings, basement slabs or walls (Brandl, 2006; Fromentin, Pahud, Laloui, \& Moreni, 1999; Laloui, Moreni, \& Vulliet, 2003). The classical way in which thermo-active foundations are used results in cyclic changes in the surrounding ground temperature (approximately $12{ }^{\circ} \mathrm{C}$ ) over a range of 4 to $30{ }^{\circ} \mathrm{C}$ (Péron, Knellwolf, \& Laloui, 2011). To study the temperature effect on ground structures, the complex interactions between temperature variations and induced stresses or deformations, which may affect long-term structure performance, must be considered (McCartney, LaHaise, LaHaise, \& Rosenberg, 2010).

The thermo-hydro-mechanical behaviour of saturated soils has been studied over the past 45 years, including the effect of temperature on shear strength, yielding and critical-state soil properties. The impact of temperature on the shear strength of soil is complex. A number of studies (De Bruyn \& Thimus, 1996; Lingnau, Graham, Yarechewski, Tanaka, \& Gray, 1996; Mitchell, 1964; Sherif \& Burrous, 1969) have reported that heating decreases the shear strength of soil, whereas others (Abuelnaga, Bergado, \& Chaiprakaikeow, 2006; Cekerevac \& Laloui, 2004; Houston, Houston, \& Williams, 1985; Laloui \& Cekerevac, 2008; Noble \& Demirel, 1969; Tanaka, Graham, \& Crilly, 1997) have obtained the opposite results. These studies show that an increase in temperature has complex and contradictory effects on the shear strength of a soil; for example, a decrease in the viscosity of the pore water due to changes in temperature would tend to decrease the shear strength, whereas the thermal volume change of the soil's components would tend to increase the shear strength. The dominance of one 
phenomenon or the other depends on the nature of the soil, its initial state (its water content and density) and the applied mechanical load ( Tang, 2005, Eslami, 2014). The stress history (over-consolidated or normally consolidated conditions) also has a major impact on the permanent volume change after drainage during heating which modifies the shear strength (e. g. Baldi, Hueckel, \& Pellegrini, 1988).

In unsaturated soils especially in compacted soils, the number of studies on the effect of temperature variation is limited despite their wide application in the field of geo-environmental engineering. Indeed, studying unsaturated soils is more complex than studying saturated soils, as more parameters need to be considered, including the measurement and control of negative pore water pressure (suction) and temperature and boundary conditions. In compacted soils, both the initial water content and the initial density influence the mechanical behaviour of soils. In fact, these soils do not have the same structure on the dry side and on the wet side of the optimum (Lambe, 1958). Therefore, the study of the mechanical behaviour of compacted soils should take into account the initial position of the soil on the compaction curve.

As the properties of soil-structure interface can influence highly the friction and the bearing capacity of the structures, the evaluation of the effect of temperature on the mechanical properties of the soil-structure interface requires also special attention. In the literature, there are various experimental methods under isothermal conditions for studying the behaviour of the soil-structure interface, such as the direct shear test (Boulon, 1989; Desai, Drumm, \& Zaman, 1985) and the simple shear test (Kishida \& Uesugi, 1987; Zeghal \& Edil, 2002). But, it is hard to find studies focused on the temperature effect on the soil-structure interface parameters. For example, Stesky (1978) reviewed the effect of high temperatures on the friction strength of faulted and jointed rocks. Under some conditions, the friction strength increased with increasing 
temperature and under other conditions, it remained unchanged or decreased with increasing temperature.

Penetrometer tests involve pushing a probe into the soil and measuring the evolution of cone resistance $\left(q_{c}\right)$ and friction sleeve resistance $\left(f_{s}\right)$. In this study, a minipenetrometer method was developed to quantify evolution of these parameters for two unsaturated compacted soils in response to soil temperature changes.

In the following sections, the mini-penetration test and associated parameters are described. The results of several tests on two different clayey soil samples are presented and discussed. Each one of these soils was compacted at preselected initial dry density and initial water content levels and then submitted to monotonic temperature variations from 1 to $70{ }^{\circ} \mathrm{C}$.

\section{Materials and methods}

Different soil samples compacted directly in CBR moulds were tested by measuring the force needed to introduce a probe at a constant penetration rate.

\subsection{Basic characterisation of materials}

Two different types of compacted materials were studied. The first was an illitic soil named Arginotech ${ }^{\circledR}$ from the east of Germany. It contains $77 \%$ illite, $10 \%$ kaolinite, $12 \%$ calcite and traces of quartz and feldspar. Illite is a non-swelling clay present in variable proportions in soils due to mineral illitisation (Lynch, 1997). It has been reported to be sensitive to temperature (Tanaka et al., 1997), with an observed decrease in the yield locus of illite with increasing temperature (from 28 to 65 and $100{ }^{\circ} \mathrm{C}$ ).

The second tested material was a mixture of 50\% kaolinite B24 and 50\% Hostun sand. Kaolinite B24 is a type of sedimentary clay from the Charente basin in southwest France. Hostun sand is a siliceous sand from the southeast of France. These two 
materials were oven-dried separately for at least 24 hours $\left(60^{\circ} \mathrm{C}\right)$ and then mixed in the desired proportions.

The basic characterisation of each material included determination of its Atterberg limits (AFNOR, 1993) and its Proctor curve (AFNOR, 1999). The liquid limit (LL), the plastic limit (PL), the plasticity index (PI), the optimum water content and the maximum dry density (Proctor compaction) are listed in Table 1 for each material. The optimum water content and the maximum dry density were $31.3 \%$ and $1.43 \mathrm{Mg} / \mathrm{m}^{3}$, respectively, for the illitic material and $13 \%$ and $1.90 \mathrm{Mg} / \mathrm{m}^{3}$, respectively, for the kaolinite-sand mixture (Figure 1). Therefore the compaction curves showed that the dry density varies from 1.22 to $1.43 \mathrm{Mg} / \mathrm{m}^{3}$ for the illitic soil, and from 1.60 to $1.90 \mathrm{Mg} / \mathrm{m}^{3}$, for the kaolinite-sand mixture, consequently the mixture has a denser structure.

The particle size distributions of the soils were determined using a laser diffraction particle size analyser (Malvern Mastersizer 2000®) (Figure 2). Almost 85\% of the particles of the illitic material are smaller than $0.002 \mathrm{~mm}$ (clay particles), and the remaining $15 \%$ are smaller than $0.02 \mathrm{~mm}$ (silt particles). The particle size distribution of the kaolinite-sand mixture reflects a coarser composition, with $50 \%$ clay and silt particles and 50\% sand. According to the French standard for soil classification (GTR, 2000), the illitic material is classified as an A3, and the kaolinite-sand mixture is classified as an A1. According to the Unified Soil Classification System (Standard A. S. T. M., 2006), the illitic material and the kaolinite-sand mixture are classified as a fat clay, $\mathrm{CH}$, and a lean clay with sand, $\mathrm{CL}$, respectively.

\subsection{Material preparation and compaction}

Samples of the two materials were mixed with water to reach the desired water contents and then packed in hermetic bags and left to homogenise for at least 24 hours. The 
samples with $117 \mathrm{~mm}$ in height were compacted in 6 layers in a CBR mould with 152 $\mathrm{mm}$ in diameter to ensure the homogeneity of the compacted specimens. Dynamic compaction was applied to each layer. The compaction level was equivalent to the standard Proctor compaction energy. The compaction curve obtained by this specific protocol was superimposed on the standard Proctor curve (Figure 1). The initial temperature of the samples was $20^{\circ} \mathrm{C}$. The samples were thermally cured at $1,20,30$, 40,50 and $70{ }^{\circ} \mathrm{C}$ for at least $24 \mathrm{~h}$ in a climatic chamber while they were packed in hermetic bags so that their water contents were kept constant.

\subsection{Experimental device}

The mini-penetration test is a laboratory test adapted from the standard static penetration test (AFNOR, 1996; Standard A. S. T. M., 1995). A probe consisting of a cone with a $60^{\circ}$ apex penetrates the sample at a constant rate of $30 \mathrm{~mm} / \mathrm{min}$ using a tension-compression system with an accuracy of $\pm 1 \mathrm{~N}$ (Figure 3). Two stainless steel probes, termed $\mathrm{P} 1$ and $\mathrm{P} 2$, were used. The lengths $(250 \mathrm{~mm})$, apex angles $\left(60^{\circ}\right)$ and maximal external diameters $(12 \mathrm{~mm})$ of the two probes were the same. However, the diameter of the rod of $\mathrm{P} 1$ was $10 \mathrm{~mm}$ and that of P2 was $12 \mathrm{~mm}$ (Figure 3). The maximum penetration length of both probes was $100 \mathrm{~mm}$. The cone resistance was measured with $\mathrm{P} 1$, whereas $\mathrm{P} 2$ provided a measure of the combined effects of the cone resistance and the friction sleeve resistance.

Three mini-penetration tests were carried out successively in each mould after the temperature equilibrium was reached. All the tests were performed at a temperature controlled room $\left(20 \pm 1{ }^{\circ} \mathrm{C}\right)$. The duration of the test was short enough to limit the exchange of temperature during the test. Table 2 shows for example the temperature variation rate during different tests for the illitic material. The position of each 
penetration test was determined to prevent edge effects (Figure 4). The tests were performed $38 \mathrm{~mm}$ from the edge of the mould, and the distance between the test points was $66 \mathrm{~mm}$. The dimensions of the mould were chosen to be large enough to avoid the edge effects, and the diameter of the probes was chosen to be large enough to measure the force. Two successive tests performed with probe P1 in the mould showed the perfect repeatability of the obtained results (Figure 5).

\section{Results}

Three different tests were carried out: the penetration of P1, the penetration of P2 and the pull-out of P2. Then, the cone resistance $\left(q_{c}\right)$ as well as the friction sleeve resistance $\left(f_{s}\right)$ during penetration and pull-out were calculated. The coupled influence of initial water content and initial dry density and the influence of temperature on the test results were studied.

\subsection{Mini-penetration curve typology}

Figure 6 presents an example of obtained curves for different tests using probes P1 and P2. The first part of the curves (AB) illustrates the penetration of the apex into the soil. This part of the test was similar with both probes, as their apex angle and diameter were identical. Part BC is specific to P1. As the diameter of P1 was less than that of its apex, the friction sleeve resistance could be considered negligible from point B onward, and the force reached a constant value $Q_{c}$ over BC for the homogeneous soil. The cone resistance $\left(q_{c}\right)$ was calculated according to equation (1).

$$
q_{c}=Q_{c} /\left(\pi R_{c}^{2}\right)
$$

where $R_{c}$ is the maximum radius of the conical apex and $Q_{c}$ is the force on the cone. 
Part BD of the curve (Figure 6) is specific to the P2 test, in which the measured force $\left(Q_{t}\right)$ is the sum of the force on the cone and the force on the friction sleeve. $Q_{t}$ increased as the probe came into contact with the soil. The friction sleeve resistance $\left(f_{s}\right)$ is the quotient of the difference between $Q_{t}$ and $Q_{c}$ and the lateral surface of the probe in contact with the sample for penetration tests (Equation 2).

$$
f_{s}=\left(Q_{t}-Q_{c}\right) /\left(2 \pi R_{c}\left(L-L_{c}\right)\right)
$$

where $\mathrm{L}$ is the penetration length and $\mathrm{L}_{\mathrm{c}}$ is the height of the cone apex.

After the penetration test, the pull-out test was performed with probe $\mathrm{P} 2$. In this case, there was no force on the cone, and the force on the friction sleeve in tension was measured directly. The first part of the curve (EF) shows the high force required to initiate the pull-out. Part FG corresponds to the force on the friction sleeve of the soilprobe interface $\left(Q_{s}{ }^{*}\right)$. Lastly, for part GA, the probe was out of the soil, and there was no friction sleeve resistance. The friction sleeve resistance in tension $\left(f_{s}^{*}\right)$ is the quotient of $Q_{s}{ }^{*}$ and the lateral surface of the probe in contact with the sample for pull-out tests (Equation 3):

$$
f_{s}^{*}=\left(Q_{s}^{*}\right) /\left(2 \pi R_{c}(L-L c)\right)
$$

\subsection{Coupled influence of water content and dry density at $20^{\circ} \mathrm{C}$}

In this section, the effects of initial water content and dry density on the measured and calculated strengths at $20{ }^{\circ} \mathrm{C}$ are presented. First, the cone resistance results are presented, and then the friction sleeve resistance results for the penetration and pull-out tests are discussed. Table 3 to Table 5 show the water contents $(w)$ and dry densities $\left(\rho_{d}\right)$ of the compacted samples studied in this section. The compaction curves are also presented in the figures to simplify the study of coupled influence of initial water 
content and dry density.

\section{Cone resistance}

Figure 7 (a) presents the P1 penetration force measured for illitic samples prepared at various water contents and dry densities. The samples S4 and S7 were prepared at the same initial dry density $\left(1.38 \mathrm{Mg} / \mathrm{m}^{3}\right)$; therefore, the difference of $190 \mathrm{~N}$ between the measured force (320 N for S4 and $130 \mathrm{~N}$ for S7) could only be due to the water content difference: $w=29.8 \%$ for $\mathrm{S} 4$ and $w=32.7 \%$ for $\mathrm{S} 7$.

The BC parts of the curves are stable, which indicates that the prepared samples are homogeneous. Measured force $\left(Q_{c}\right)$ increased with decreasing water content. Cone resistance $\left(\mathrm{q}_{\mathrm{c}}\right)$ was then calculated using equation 1(Figure $7(\mathrm{~b})$ ). Then, the mean of the cone resistance obtained in the linear part (BC) for a penetration depth between $50 \mathrm{~mm}$ and $100 \mathrm{~mm}$ in the P1 test was used as the mean cone resistance for the test. These limits were selected because the values of cone resistance are homogenous and stable. Figure 8 superimposes the mean cone resistance $\left(q_{c}\right)$ onto the compaction curve for each material.

- For the illitic samples, the maximum values were obtained for the materials on the dry side $\left(q_{c}=11,270 \mathrm{kPa}\right)$, and $q_{c}$ decreased linearly when approaching the optimum $(1,800 \mathrm{kPa})$. On the wet side of the optimum, $q_{c}$ changed slowly, trending toward approximately $1,000 \mathrm{kPa}$ (Figure 8(a)).

- For the kaolinite-sand mixture, a rapid decrease in $q_{c}$ on the dry side of the optimum and a slow decrease on the wet side were observed. The maximum value was also located on the dry side $\left(q_{c}=7,055 \mathrm{kPa}\right)$ (Figure $\left.8(\mathrm{~b})\right)$. 
For the kaolinite-sand mixture, the cone resistance at the optimum $(3,800 \mathrm{kPa})$ was higher than for the illitic material $(1,800 \mathrm{kPa})$. This could be due to different nature of the studied soils and the high density of the mixture $\left(1.90 \mathrm{Mg} / \mathrm{m}^{3}\right.$ for the kaolinitesand mixture and $1.43 \mathrm{Mg} / \mathrm{m}^{3}$ for the illitic material). However, the behaviour of the two studied materials was similar overall, as the maximum values of $q_{c}$ were always on the dry side of the optimum water content, and there was a pronounced decrease in the measured parameters on the dry side of the optimum and a slow decrease on the wet side of the optimum.

\section{Friction sleeve resistance for penetration tests}

Figure 9 (a) presents the total force $\left(Q_{t}\right)$ using probe P2 (curve ABD). $Q_{t}$ decreased with increasing water content. This result is coherent with the evolution of the force on the cone $\left(Q_{c}\right)$. The difference between the curves obtained with P1 (Figure 7 (a)) and the curves obtained with P2 (Figure 9 (a)) provided the force on the friction sleeve (Figure 9 (b)). $f_{s}$ increased with penetration depth due to an increase in the soil-probe interface. For each test and each penetration depth, friction sleeve resistance $\left(f_{s}\right)$ was calculated (Equation 2) (Figure 10). The mean values of $f_{s}$ for penetration depths between $50 \mathrm{~mm}$ to $100 \mathrm{~mm}$ were used to obtain the mean friction sleeve resistance for the test (Figure 11).

- For the illitic material, there was a peak in the friction sleeve resistance according to the soil density and water content evolution. This could be due to the compacted soil microstructure, which is irregularly aggregated on the dry side (Lambe, 1958). In fact, on the dry side and for low water contents, the effective contact surface between the probe and the soil is small and irregular. As the initial water content increases, the contact surface increases, and the friction sleeve resistance also increases 
until the peak. From the peak value, $f s$ decreases because of the lubrication due to the increase in water content.

For the illitic material, a maximum of $420 \mathrm{kPa}$ for $f s$ was reached on the dry side of the optimum for the sample prepared with a $27.9 \%$ water content $(3.4 \%$ less than the optimum water content). After that point, $f_{s}$ decreased quickly, reaching $76 \mathrm{kPa}$ for samples prepared with a $32.7 \%$ water content (optimum water content $+1.4 \%$ ). On the wet side of the optimum, the decrease in $f_{s}$ was smaller than that on the dry side (Figure 11Figure 11(a)).

- For the kaolinite-sand mixture, the maximum measured friction sleeve resistance was $180 \mathrm{kPa}$; this was less than that of the illitic material, which could be due to the nature of the material. As with the illitic material, friction sleeve resistance decreased quickly on the dry side but slowly on the wet side, and it reached a minimum of $13 \mathrm{kPa}$ (Figure 11(b)). Comparing the friction sleeve resistances at different water contents and dry densities yields the same conclusion as the examination of the cone resistance results for the kaolinite-sand mixture samples: as the water content decreases, the friction sleeve resistance increases.

The increase in the studied parameters (cone resistance and friction sleeve resistance) with decreasing water content on the dry side of the optimum water content could be related to the increase in the matric suction, which represents the combined effects of the forces holding the water in the soil.

Given the correlation between shear strength (modulus) and penetration test parameters, the results can be compared with those in the literature. The observed trends for the studied parameters in the present study are consistent with the results obtained by Sawangsuriya, Edil, \& Bosscher (2008) for the normalised small-strain shear modulus of certain soils. The soils tested were a lean clay, a silt and a clayey sand, and 
they were compacted over a range of moulding water contents from $4 \%$ dry of optimum to $4 \%$ wet of optimum. They determined the modulus based on a shear wave propagation technique using bender elements. They observed that the shear modulus increases on the dry side of optimum with increasing suction and decreasing moulding water content. They also found that if any peak occurred, it was on the dry side of the optimum. These results are also consistent with those obtained by Wiebe et al. (1998), who studied the evolution of the shear strength for a sand-bentonite mixture prepared at various degrees of saturation $\left(S_{r}\right)$. Tests carried out at the same temperature showed that as $S_{r}$ decreased from $98 \%$ to $50 \%$, shear strength increased. However, for a decrease in $S_{r}$ from $50 \%$ to $35 \%$, they recorded a decrease in shear strength. They attributed this behaviour to the variation in suction and the deformability. In fact, at high water contents $\left(S_{r}=98 \%\right)$, suctions are low and aggregates are deformable, which results in low shear strengths. At low water contents $\left(S_{r}=50 \%\right)$, the suction is high, and therefore, the increase in the internal stiffness leads to a higher shear strength. For the lowest water contents $\left(S_{r}=35 \%\right)$, the decrease in the shear strength is due to the decrease in the stiffness of aggregates, which become more brittle. Uchaipichat \& Khalili (2009) also studied the shear strength of a silt under different suctions $(0,100$ and $300 \mathrm{kPa}$ ). The deviatoric stress increased with increasing suction, and the maximum deviator stress occurred in a shear test with an initial matric suction of $300 \mathrm{kPa}$. They concluded that the expansion of the yield locus with increasing suction could be due to the suction-hardening phenomenon in unsaturated soils.

\section{Friction sleeve resistance for pull-out tests}

Figure 12(a) illustrates the force increase with decreasing water content in the pull-out tests. These results are similar to those obtained for the penetration tests. As with the 
penetration tests, the measured forces for the mixture are lower than those of the illitic material. For each test and each penetration depth, the friction sleeve resistance for the pull-out test $\left(f_{s}^{*}\right)$ was calculated using Equation 3 (Figure 12Figure 12(b)). The mean value of $f_{s}^{*}$ at penetration depths of $80 \mathrm{~mm}$ to $90 \mathrm{~mm}$ was taken as the friction sleeve resistance for the pull-out test (Figure 13) because, for this parameter, the values were constant and homogeneous.

- For the illitic material, as with the penetration test, there was a peak for the friction sleeve for the same sample, with a maximum absolute value of friction sleeve resistance of $280 \mathrm{kPa}$ on the dry side of the optimum. The absolute values of friction sleeve resistance $\left(f_{s}^{*}\right)$ decreased, reaching $52 \mathrm{kPa}$ for samples prepared on the wet side of the optimum. (Figure 13(a)). The existence of a peak for friction sleeve resistance for the illitic material could be due to the evolution of the force on the friction sleeve, as explained for the penetration tests in the previous section.

- For the kaolinite-sand mixture, the absolute values of the evolution of friction sleeve resistance are the same as in the penetration test, starting from a maximum absolute value of friction sleeve resistance $(140 \mathrm{kPa})$ and reaching the small values on the wet side of the optimum (Figure 13(b)).

\subsection{Coupled influence of water content and dry density at different temperatures}

Some samples of illitic material and kaolinite-sand mixture were prepared at various water content and dry density then cooled down to $1^{\circ} \mathrm{C}$ or heated to $30,40,50$ or $70^{\circ} \mathrm{C}$ to study the effect of monotonic temperature variation (Table 4 and Table 5). Penetration and pull-out tests were performed and cone resistance and friction sleeve resistance were calculated for each sample as explained in the section 3.2. In this section the final results are presented and discussed. 
- For the illitic material, 12 tests at $1{ }^{\circ} \mathrm{C}, 11$ tests at $40{ }^{\circ} \mathrm{C}$ and 4 tests at $70{ }^{\circ} \mathrm{C}$ were performed. Figure 14(a) presents the mean cone resistance $\left(q_{c}\right)$ superimposed onto the compaction curve at different temperatures. As with the tests at $20{ }^{\circ} \mathrm{C}$, the maximum values of the cone resistance were obtained on the dry side of the optimum for all temperature values. The peak values of the friction sleeve resistance were obtained on the dry side of the optimum in the penetration and pull-out tests (Figure 15(a) and Figure $16(\mathrm{a})$ ). For the tests at $1{ }^{\circ} \mathrm{C}$, all the studied parameters were close to those obtained at $20{ }^{\circ} \mathrm{C}$, therefore it is hard to deduce a potential impact of temperature. For the tests at $40^{\circ} \mathrm{C}$, cone resistance and friction sleeve resistance were not affected by temperature variations for the samples prepared on the wet side of the optimum. In contrast, for the samples prepared on the dry side of the optimum, increasing temperature tended to decrease friction sleeve resistance. Cone resistance changed slightly with increasing temperature but did not vary significantly (Figure 14(a), Figure 15(a) and Figure 16(a)). The tests at $70{ }^{\circ} \mathrm{C}$ carried out on the dry side of the optimum were similar to the obtained results at $40{ }^{\circ} \mathrm{C}$ : as the temperature increased, the studied parameters decreased. This temperature impact was more evident for friction sleeve resistance than for the cone resistance. These results are consistent with those obtained by Wiebe et al. (1998), who studied the effect of temperature on soil shear strength. Their results showed that shear strength decreases with increasing temperature and that the effect of temperature is more marked when the degree of saturation is low, i.e., on the dry side of the optimum. They concluded that the decrease in resistance is caused by the decrease in suction due to heating. The results of Uchaipichat \& Khalili, 2009, for temperature and suction controlled shear tests showed a decrease in shear stress with increasing temperature for the same suction. Increasing temperature caused a decrease in the yield locus due to the thermal softening. The decrease in the studied parameters 
with increasing temperature could be due to the reorganisation of the soil microstructure and the decreased viscosity of water. Indeed, the decrease in pore water viscosity can facilitate sliding between grains and the soil-probe interface, thereby reducing the measured strengths. This could explain the observed temperature effect on the dry side of optimum for the compacted illitic material.

- For the kaolinite-sand mixture, 3 tests at $1{ }^{\circ} \mathrm{C}, 3$ tests at $30{ }^{\circ} \mathrm{C}$ and 2 tests at 50 ${ }^{\circ} \mathrm{C}$ were performed. The variation of the parameters according to the soil density and water content evolution is similar to $20{ }^{\circ} \mathrm{C}$ at 1,30 and $50{ }^{\circ} \mathrm{C}$ (Figure $14(\mathrm{~b})$, Figure 15(b) and Figure 16(b)). Cone resistance was not strongly affected by temperature variations between 1 and $50^{\circ} \mathrm{C}$ (Figure 14(b)). For the friction sleeve resistance in the penetration and pull-out tests, the evolution of the temperature did not affect the studied parameters, and excluding two mentioned tests for cone resistance, there was no significant variation with temperature $\left(1,20,30\right.$ and $\left.50{ }^{\circ} \mathrm{C}\right)$, as shown in Figure 15 (b) and Figure 16(b). This could be due to the high density of the mixture limiting the reorganisation of the soil microstructure.

\section{Conclusions}

The purpose of this study was to propose a simple method to measure the effects of temperature variations on the cone resistance $\left(q_{c}\right)$ and friction sleeve resistance $\left(f_{s}\right)$ of compacted soil samples prepared at various initial water contents and densities. A minipenetration test was developed, and the results obtained showed that the test is repeatable and reliable. For the studied compacted soils, decreasing the water content increased both cone resistance and friction sleeve resistance. Overall, the dry density of the soil seems to have less impact on the penetration parameters than the water content. Both cone resistance and friction sleeve resistance vary more sharply on the dry side of 
the compaction curve than on the wet side.

For the illitic material compacted on the dry side of the optimum water content, a slight decrease in cone resistance and a large decrease in friction sleeve resistance were observed with increasing temperature. On the wet side, the changes in cone resistance and friction sleeve resistance with changes in temperature were not significant. For the kaolinite-sand mixture, on both the wet and dry sides of the compaction curve, the temperature effect on the penetration parameters was negligible. Indeed, the initial water contents and dry densities, as well as the nature of the soil, could be considered the most important factors affecting the influence of temperature variations on the studied parameters.

Of note, the samples in this study were maintained at constant water contents while the temperature was varied. The coupled evolution of the temperature and the water content should also be considered.

\section{ACKNOWLEDGEMENTS}

This study was part of the GECKO research program funded by ANR.

\section{BIBLIOGRAPHY}

Abuelnaga, H., Bergado, D., \& Chaiprakaikeow, S. (2006). Innovative thermal technique for enhancing the performance of prefabricated vertical drain during the preloading process. Geotextiles and Geomembranes, 24(6), 359-370.

AFNOR. (1993). NF P94-051 Sols: reconnaissance et essais ; Détermination des limites d'Atterberg - Limite de liquidité à la coupelle- Limite de plasticité au rouleau. (p. 15). Paris, France: Association Française de Normalisation.

AFNOR. (1996). NF P94-113 Sols: reconnaissance et essais ; Essai de pénétration statique (p. 16). Paris, France: Association Française de Normalisation.

AFNOR. (1999). NF P 94-093 Sols : Reconnaissance et essais Détermination des références de compactage d 'un matériau. Essai Proctor Normal-Essai Proctor Modifié (p. 18). Paris, France: Association Française de Normalisation. 
Baldi, G., Hueckel, T., \& Pellegrini, R. (1988). Thermal volume changes of the mineralwater system in low-porosity clay soils. Canadian Geotechnical Journal, 25(4), 807-825. Retrieved from http://www.nrcresearchpress.com/doi/abs/10.1139/t88089

Boulon, M. (1989). Basic features of soil structure interface behaviour. Computers and Geotechnics, 7(1), 115-131.

Brandl, H. (2006). Energy foundations and other thermo-active ground structures. Géotechnique, 56(2), 81-122.

Cekerevac, C., \& Laloui, L. (2004). Experimental study of thermal effects on the mechanical behaviour of a clay. International Journal for Numerical and Analytical Methods in Geomechanics, 28(3), 209-228.

De Bruyn, D., \& Thimus, J. F. (1996). The influence of temperature on mechanical characteristics of Boom clay: The results of an initial laboratory programme. Engineering Geology, 41, 117-126.

Desai, C., Drumm, E., \& Zaman, M. (1985). Cyclic Testing and Modeling of Interfaces. Journal of Geotechnical Engineering, 111(6), 793-815.

Eslami, H. (2014). Impact of the thermo-active geostructures on the hydro-mechanical behavior of the soils. University of Lorraine.

Fromentin, A., Pahud, D., Laloui, L., \& Moreni, M. (1999). Pieux échangeurs: conception et règles de pré-dimensionnement. Revue Française de Génie Civil, 3(6), 387-421.

GTR. (2000). Réalisation des remblais et des couches de forme (p. 102). Paris: Laboratoire Central des Ponts et Chaussées.

Houston, S., Houston, W., \& Williams, N. (1985). Thermo-Mechanical Behavior of Seafloor Sediments. Journal of Geotechnical Engineering, 111(11), 1249-1263.

Kishida, H., \& Uesugi, M. (1987). Tests of the interface between sand and steel in the simple shear apparatus. Geotechnique, 37(1), 45-52.

Laloui, L., \& Cekerevac, C. (2008). Non-isothermal plasticity model for cyclic behaviour of soils. International Journal for Numerical and Analytical Methods in Geomechanics, 32(5), 437-460.

Laloui, L., Moreni, M., \& Vulliet, L. (2003). Comportement d'un pieu bi-fonction, fondation et échangeur de chaleur. Canadian Geotechnical Journal, 40(2), 388402.

Lambe, T. W. (1958). The structure of compacted clay. Journal of the Soil Mechanics and Foundations Division, ASCE, 84, 1-34. 
Lingnau, B., Graham, J., Yarechewski, D., Tanaka, N., \& Gray, M. N. (1996). Effects of temperature on strength and compressibility of sand-bentonite buffer. Engineering Geology, 41(1), 103-115.

Lynch, F. L. (1997). Frio Shale Mineralogy and the Stoichiometry of the Smectite-toIllite Reaction: The Most Important Reaction in Clastic Sedimentary Diagenesis. Clays and Clay Minerals, 45(5), 618-631.

McCartney, J., LaHaise, D., LaHaise, T., \& Rosenberg, J. (2010). Application of Geoexchange Experience to Geothermal Foundations. Art of Foundation Engineering Practice (GSP 198), 411-422.

Mitchell, J. K. (1964). Shearing resistance of soils as a rate process. Journal of Soil Mechanics \& Foundations Div, 90(Proc. Paper 3773).

Noble, C. A., \& Demirel, T. (1969). Effect of temperature on strength behavior of cohesive soil. Highway Research Board Special Report 103.

Péron, H., Knellwolf, C., \& Laloui, L. (2011). A method for the geotechnical design of heat exchanger piles. In Proceedings of the American Society of Civil Engineers, Geo-Frontiers, (Vol. 397, pp. 470-479). Dallas, USA.

Sawangsuriya, A., Edil, T. B., \& Bosscher, P. J. (2008). Modulus-suction-moisture relationship for compacted soils. Canadian Geotechnical Journal, 45(7), 973-983.

Sherif, M., \& Burrous, C. (1969). Temperature effects on the unconfined shear strength of saturated, cohesive soil. Highway Research Board Special Report, 103.

Standard A. S. T. M. (1995). D5778-95 Standard test method for performing electronic friction cone and piezocone penetration testing of soils (Vol. 04, p. 19). West Conshohocken, PA www. ASTM. org: ASTM International.

Standard A. S. T. M. (2006). D2487 Standard practice for classification of soils for engineering purposes (Unified Soil Classification System) (Vol. i, p. 12). West Conshohocken, PA www. ASTM. org: ASTM International.

Stesky, R. M. (1978). Rock Friction-Effect of Confining Pressure, Temperature, and Pore Pressure. Pure and Applied Geophysics, 116(4-5), 609-704.

Tanaka, N., Graham, J., \& Crilly, T. (1997). Stress-strain behaviour of reconstituted illitic clay at different temperatures. Engineering Geology, 47(4), 339-350.

Tang, A. (2005). Effet de la température sur le comportement des barrières de confinement. École Nationale des Ponts et Chaussées. Retrieved from http://pastel.archives-ouvertes.fr/pastel-00001594/

Uchaipichat, A., \& Khalili, N. (2009). Experimental investigation of thermo-hydromechanical behaviour of an unsaturated silt. Géotechnique, 59(4), 339-353. 
Wiebe, B., Graham, J., Tang, G. X., \& Dixon, D. (1998). Influence of pressure, saturation, and temperature on the behaviour of unsaturated sand-bentonite. Canadian Geotechnical Journal, 35(2), 194-205.

Zeghal, M., \& Edil, T. (2002). Soil structure interaction analysis: modeling the interface. Canadian Geotechnical Journal, 628, 620-628. 
Table 1: Characteristics of illitic material and kaolinite-sand mixture

\begin{tabular}{cccccc}
\hline & $\begin{array}{c}\text { Liquid } \\
\text { Limit }\end{array}$ & $\begin{array}{c}\text { Plastic } \\
\text { Limit }\end{array}$ & $\begin{array}{c}\text { Plasticity } \\
\text { Index }\end{array}$ & $\begin{array}{c}\text { Optimum Water } \\
\text { Content }(\%)\end{array}$ & $\begin{array}{c}\text { Maximum Dry Density } \\
\left(\mathrm{Mg} / \mathrm{m}^{3}\right)\end{array}$ \\
\hline Illitic Material & 65 & 34 & 31 & 31.3 & 1.43 \\
\hline $\begin{array}{c}\text { Kaolinite-Sand } \\
\text { Mixture }\end{array}$ & 26.9 & 15.4 & 11.5 & 13 & 1.88 \\
\hline
\end{tabular}


Table 2: The initial and final temperature on the centre of the sample of illitic material.

\begin{tabular}{ccccc}
\hline $\begin{array}{c}\text { Initial temperature } \\
\left({ }^{\circ} \mathrm{C}\right)\end{array}$ & 1 & 20 & 40 & 70 \\
\hline $\begin{array}{c}\text { Temperature variation } \\
\text { rate }\left({ }^{\circ} \mathrm{C} / \mathrm{min}\right)\end{array}$ & 0.17 & 0 & 0.20 & 0.53 \\
\hline
\end{tabular}


Table 3: Water contents $(w)$ and dry densities $\left(\rho_{d}\right)$ of illitic samples for the results presented in figures 7, 9, 10 and 12 .

\begin{tabular}{cccccc}
\hline Sample & $w(\%)$ & $\rho_{d}\left(\mathrm{Mg} / \mathrm{m}^{3}\right)$ & $q_{c}(\mathrm{kPa})$ & $f_{s}(\mathrm{kPa})$ & $f_{s}^{*}(\mathrm{kPa})$ \\
\hline S1 & 25.8 & 1.25 & 7384 & 368 & - \\
S2 & 27.9 & 1.34 & 4446 & 418 & -281 \\
S3 & 28.9 & 1.36 & 3621 & 328 & -220 \\
S4 & 29.8 & 1.38 & 2808 & 227 & -152 \\
S5 & 30.4 & 1.43 & 2158 & 145 & -100 \\
S6 & 31.9 & 1.41 & 1519 & 88.5 & -66 \\
S7 & 32.7 & 1.38 & 1147 & 76 & -52 \\
\hline
\end{tabular}


Table 4: Water contents $(w)$ and dry densities $\left(\rho_{d}\right)$ for illitic material samples.

\begin{tabular}{|c|c|c|c|c|c|}
\hline Temperature $\left({ }^{\circ} \mathrm{C}\right)$ & $w(\%)$ & $\rho_{d}\left(\mathrm{Mg} / \mathrm{m}^{3}\right)$ & $q_{c}(\mathrm{kPa})$ & $f_{s}(\mathrm{kPa})$ & $f_{s}^{*}(\mathrm{kPa})$ \\
\hline \multirow{12}{*}{20} & 23.6 & 1.28 & 11270 & 380 & -252 \\
\hline & 25.8 & 1.25 & 7384 & 368 & - \\
\hline & 26.1 & 1.29 & 7003 & 403 & -229 \\
\hline & 26.4 & 1.27 & 6871 & 328 & -202 \\
\hline & 26.8 & 1.30 & 5747 & 392 & - \\
\hline & 27.8 & 1.33 & 5029 & 410 & - \\
\hline & 27.9 & 1.34 & 4446 & 420 & -280 \\
\hline & 28.9 & 1.36 & 3621 & 328 & -220 \\
\hline & 29.8 & 1.38 & 2808 & 227 & -152 \\
\hline & 30.4 & 1.43 & 2158 & 145 & -100 \\
\hline & 31.9 & 1.43 & 1519 & 89 & -66 \\
\hline & 32.7 & 1.38 & 1147 & 76 & -52 \\
\hline \multirow{12}{*}{1} & 24.1 & 1.24 & 8158 & 353 & -205 \\
\hline & 26.9 & 1.29 & 6117 & 391 & -212 \\
\hline & 28.1 & 1.33 & 4035 & 366 & -247 \\
\hline & 28.9 & 1.37 & 3015 & 296 & -201 \\
\hline & 29.1 & 1.36 & 3498 & 294 & -206 \\
\hline & 30.2 & 1.39 & 1850 & 150 & -99 \\
\hline & 30.5 & 1.39 & 1970 & 138 & -96 \\
\hline & 31.6 & 1.42 & 1041 & 89 & -58 \\
\hline & 32.3 & 1.41 & 1331 & 86 & -60 \\
\hline & 32.3 & 1.42 & 1346 & 77 & -56 \\
\hline & 32.3 & 1.39 & 1158 & 66 & -47 \\
\hline & 34.2 & 1.39 & 661 & 37 & -29 \\
\hline \multirow{11}{*}{40} & 25.0 & 1.26 & 7377 & 326 & -185 \\
\hline & 26.2 & 1.31 & 5595 & 293 & -193 \\
\hline & 28.1 & 1.31 & 3644 & 313 & -196 \\
\hline & 28.2 & 1.33 & 3710 & 283 & -197 \\
\hline & 29.5 & 1.40 & 2559 & 223 & -139 \\
\hline & 29.6 & 1.39 & 2480 & 192 & -134 \\
\hline & 29.6 & 1.37 & 2424 & 189 & -122 \\
\hline & 30.6 & 1.42 & 2094 & 134 & -93 \\
\hline & 31.0 & 1.43 & 1935 & 121 & -83 \\
\hline & 31.7 & 1.40 & 1530 & 91 & -63 \\
\hline & 33.0 & 1.38 & 1064 & 64 & -44 \\
\hline \multirow{4}{*}{70} & 21.4 & 1.22 & 8250 & 289 & -136 \\
\hline & 24.5 & 1.29 & 7524 & 284 & -150 \\
\hline & 26.0 & 1.31 & 5300 & 296 & -167 \\
\hline & 28.0 & 1.36 & 3938 & 319 & -215 \\
\hline
\end{tabular}


Table 5: Water contents $(w)$ and dry densities $\left(\rho_{d}\right)$ for kaolinite-sand mixture samples.

\begin{tabular}{cccccc}
\hline Temperature $\left({ }^{\circ} \mathrm{C}\right)$ & $w(\%)$ & $\rho_{d}\left(\mathrm{Mg} / \mathrm{m}^{3}\right)$ & $q_{c}(\mathrm{kPa})$ & $f_{s}(\mathrm{kPa})$ & $f_{s}^{*}(\mathrm{kPa})$ \\
\hline & 11.3 & 1.74 & 7055 & - & - \\
& 11.9 & 1.82 & 5637 & - & - \\
& 12.3 & 1.87 & 4556 & 180 & -140 \\
\multirow{3}{*}{20} & 13.0 & 1.88 & 3514 & 141 & -90 \\
& 14.2 & 1.85 & 1287 & 54 & -42 \\
& 15.1 & 1.82 & 845 & 30 & -24 \\
& 16.9 & 1.73 & 393 & 18 & -12 \\
& 18.5 & 1.66 & 198 & 13 & -8 \\
\hline \multirow{3}{*}{1} & 12.0 & 1.82 & 5863 & 191 & -182 \\
& 13.4 & 1.90 & 2320 & 100 & -70 \\
& 15.3 & 1.79 & 802 & 31 & -26 \\
\hline \multirow{2}{*}{30} & 11.7 & 1.81 & 5564 & 207 & -177 \\
& 13.2 & 1.90 & 2300 & 93 & -66 \\
& 15.0 & 1.79 & 794 & 36 & -26 \\
\hline \multirow{2}{*}{50} & 12.2 & 1.85 & 3467 & 160 & -105 \\
& 12.5 & 1.87 & 4231 & 155 & -100 \\
\hline
\end{tabular}




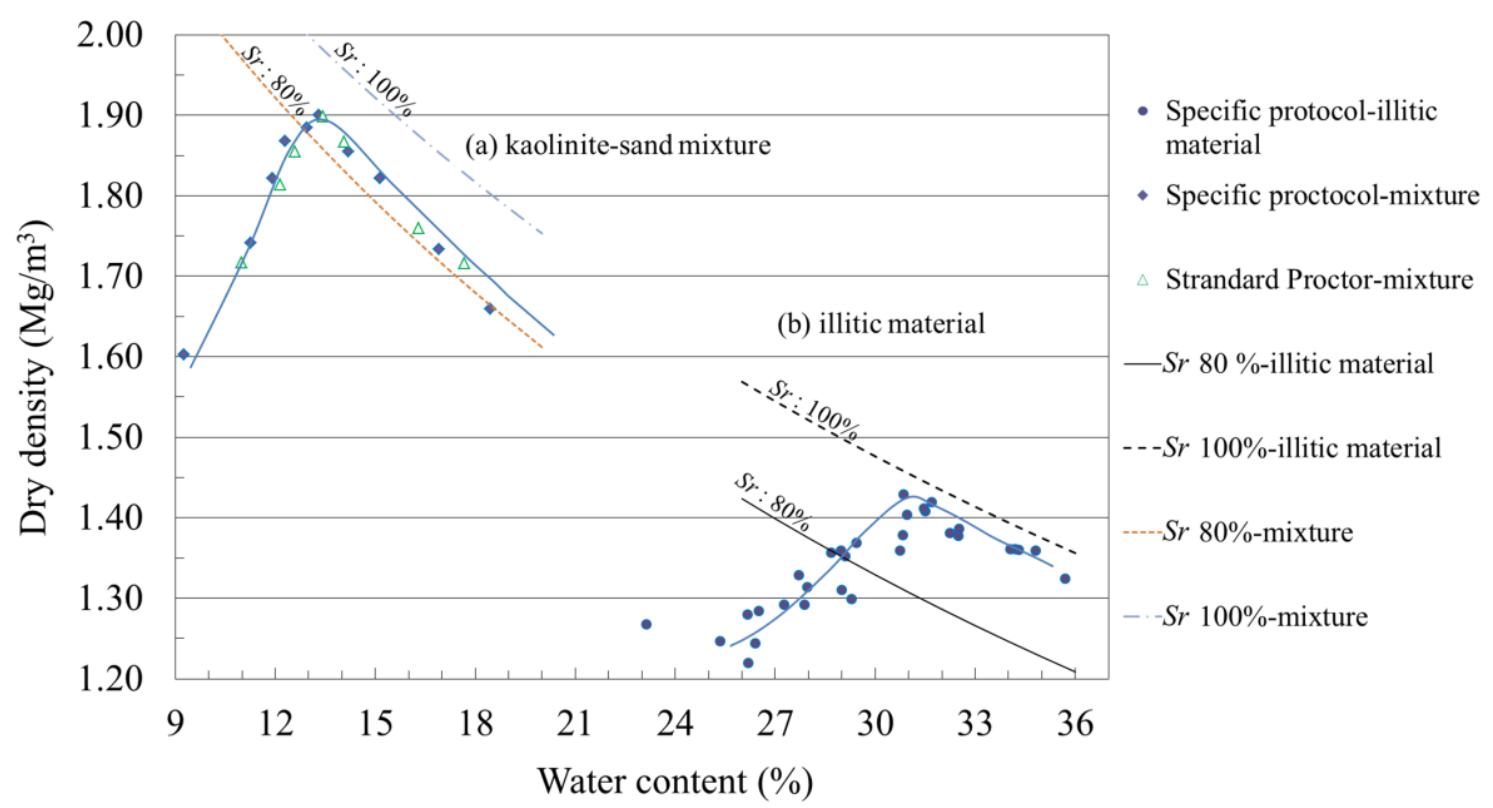

Figure 1: (a) Specific and standard compaction curves of the kaolinite--sand mixture. (b) Specific compaction curve of the illitic material. Sr: The degree of saturation. 


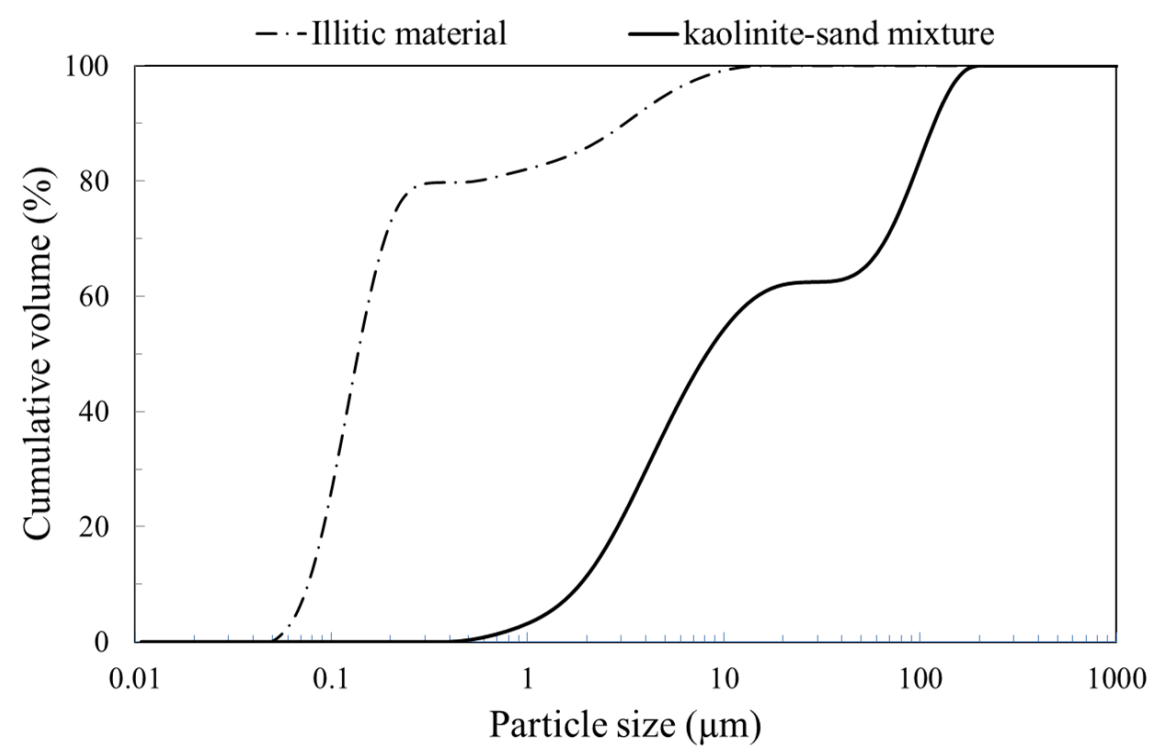

Figure 2: Particle size distribution of the tested materials. 


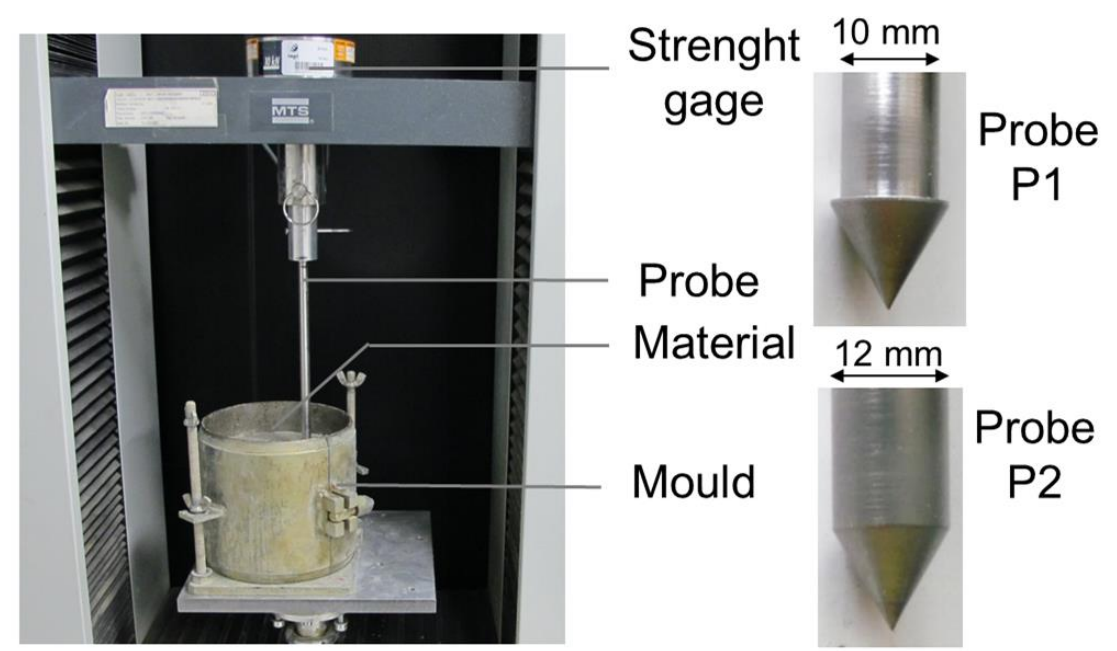

Figure 3: Mini-penetration test with the tension-compression machine and the probes for the mini-penetration test. 


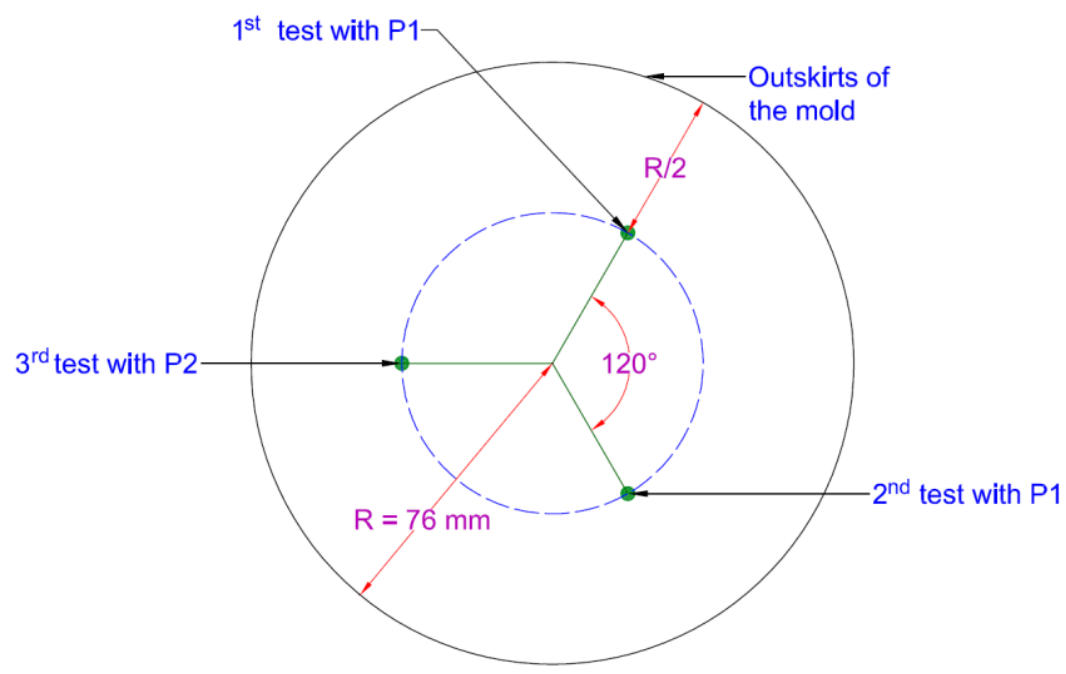

Figure 4: Positions of the penetration tests in the mould. 


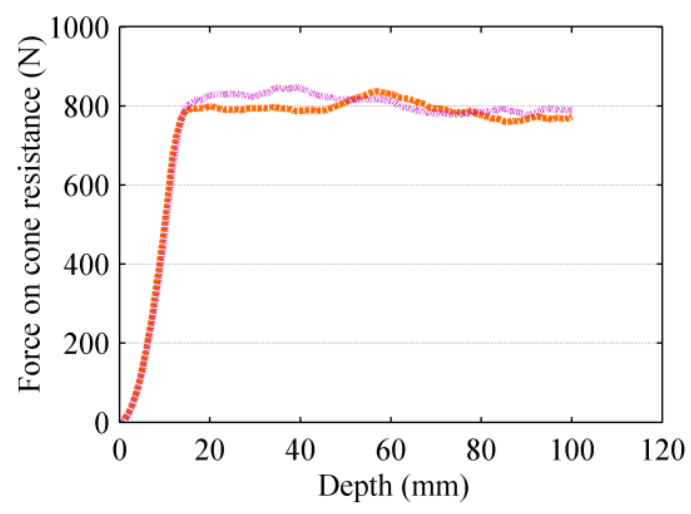

Figure 5: Force versus depth measured using probe P1. 


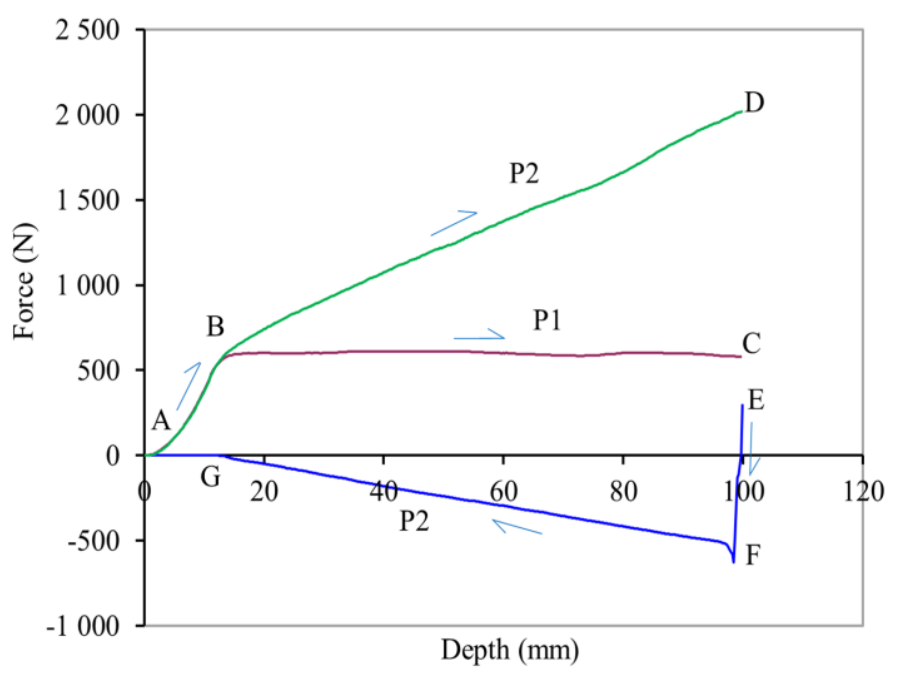

Figure 6: Force versus depth measured using probes P1 and P2 for the penetration test ( $\mathrm{ABC}$ and $\mathrm{ABD}$ ) and using probe $\mathrm{P} 2$ for the pull-out test (EFGA). 

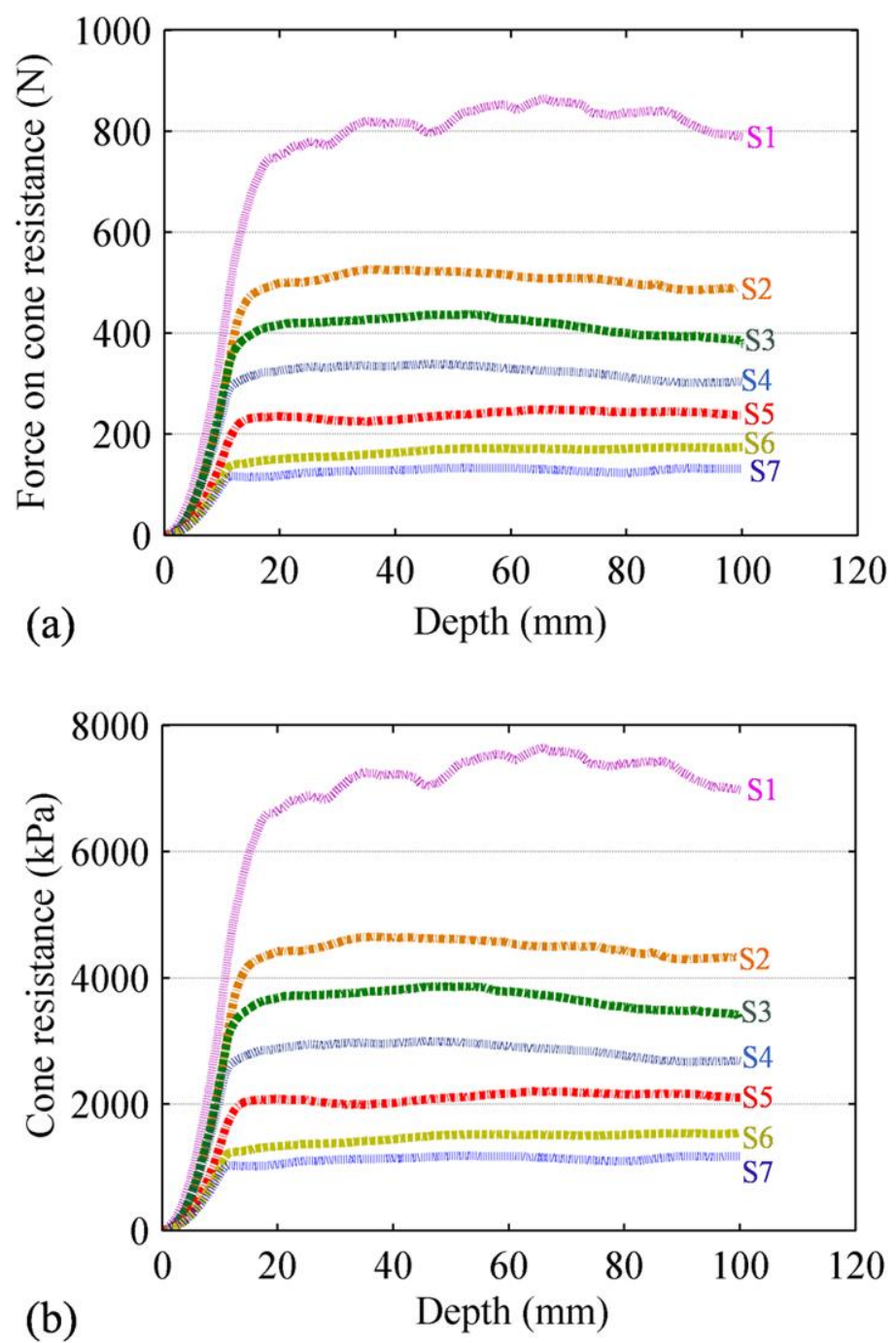

Figure 7: (a) Force measured along the penetration of P1 for samples S1 to S7. (b) Evolution of cone resistance for samples S1 to S7. 

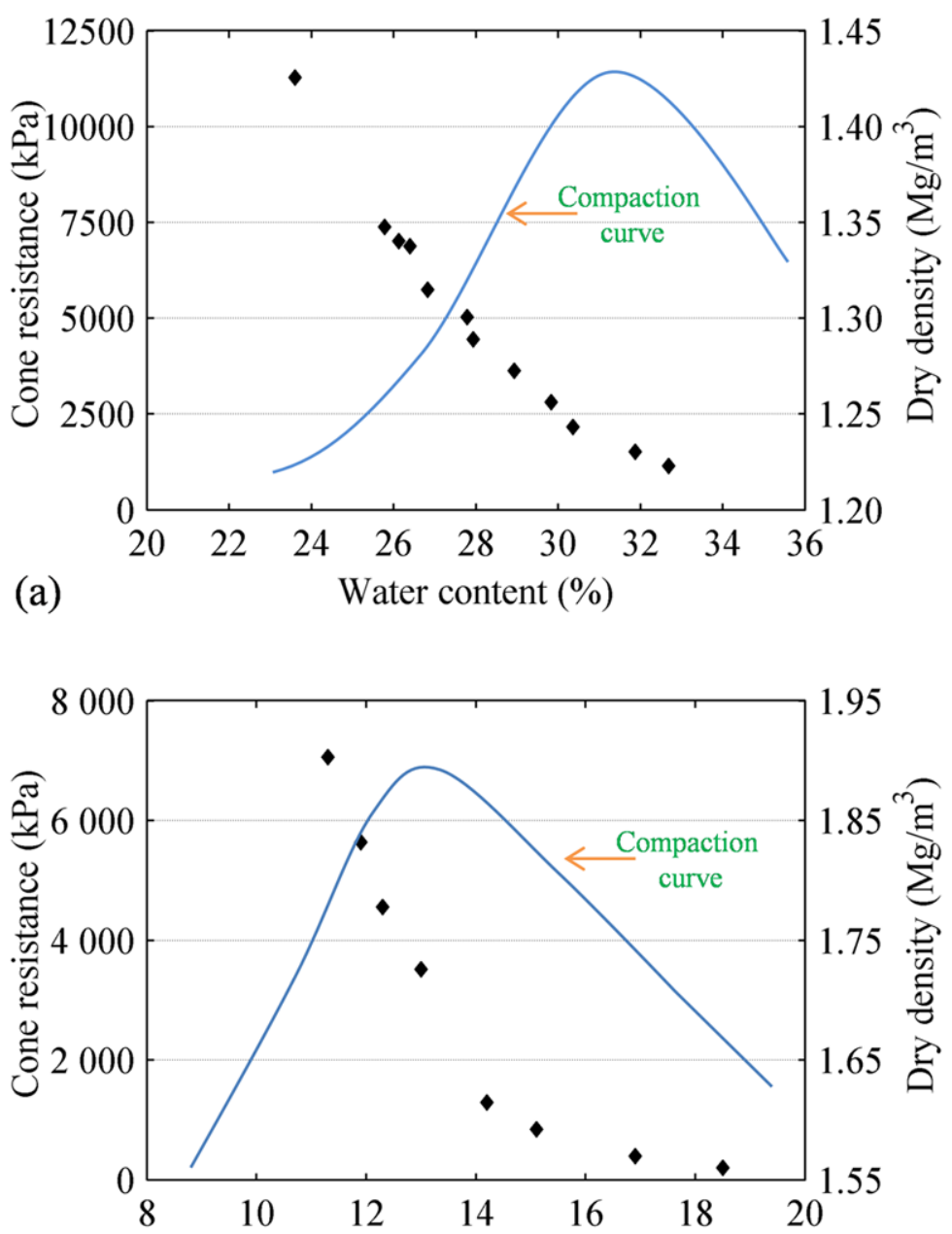

(b)

Water content (\%)

Figure 8: Mean cone resistances $\left(q_{c}\right)$ at different water contents and dry densities for the P1 tests: (a) illitic material and (b) kaolinite-sand mixture. 

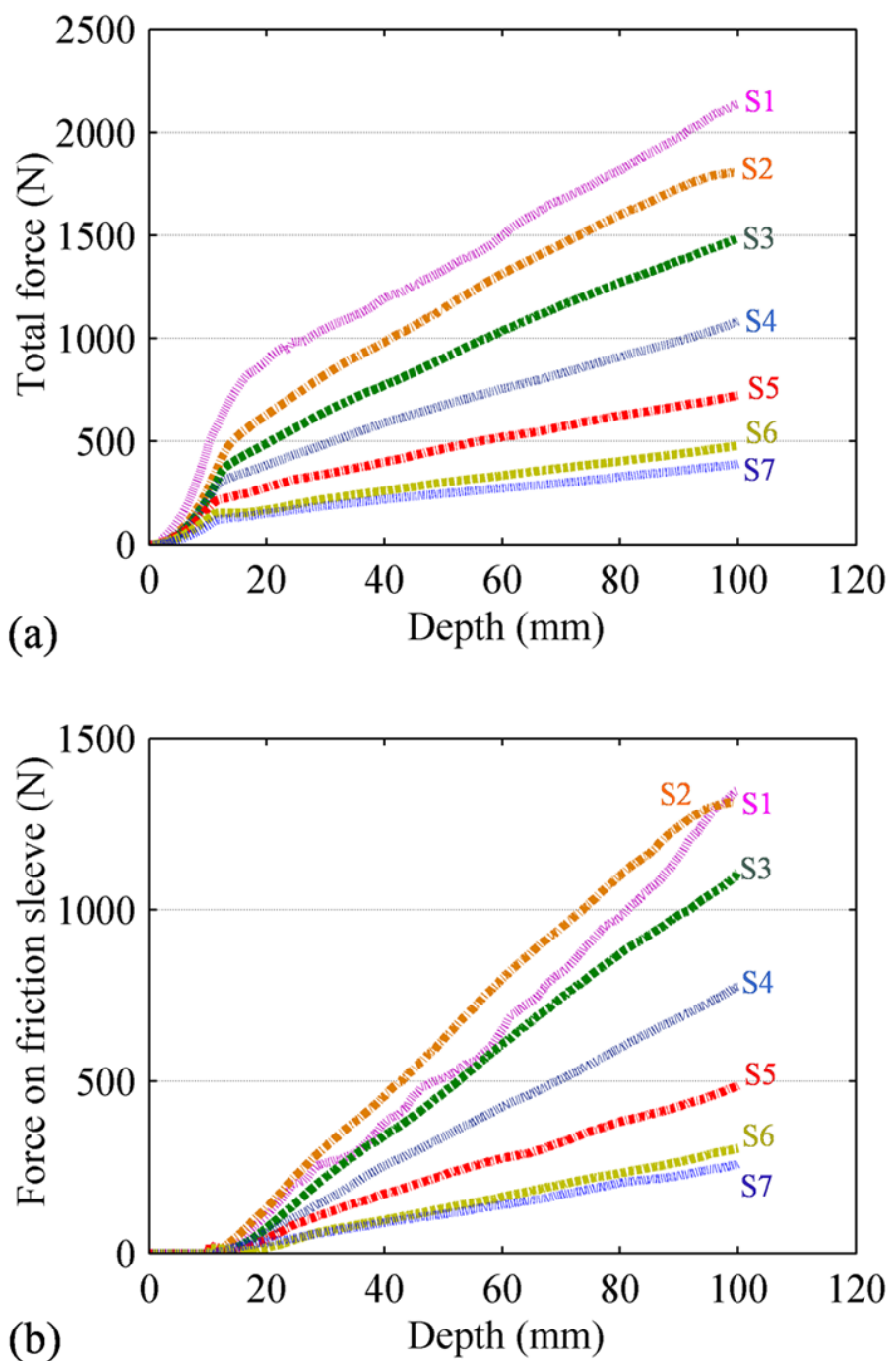

Figure 9: (a) Evolution of the total force (P2 tests) and (b) the deduced force on the friction sleeve (P2-P1) for samples S1 to S7. 


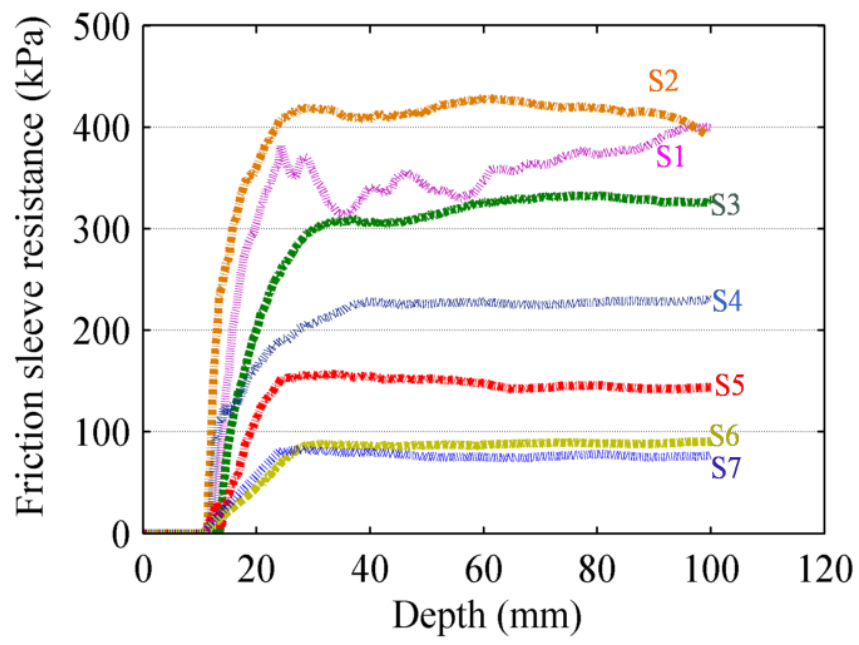

Figure 10: Evolution of the friction sleeve resistance $\left(f_{s}\right)$ for samples S1 to S7. 

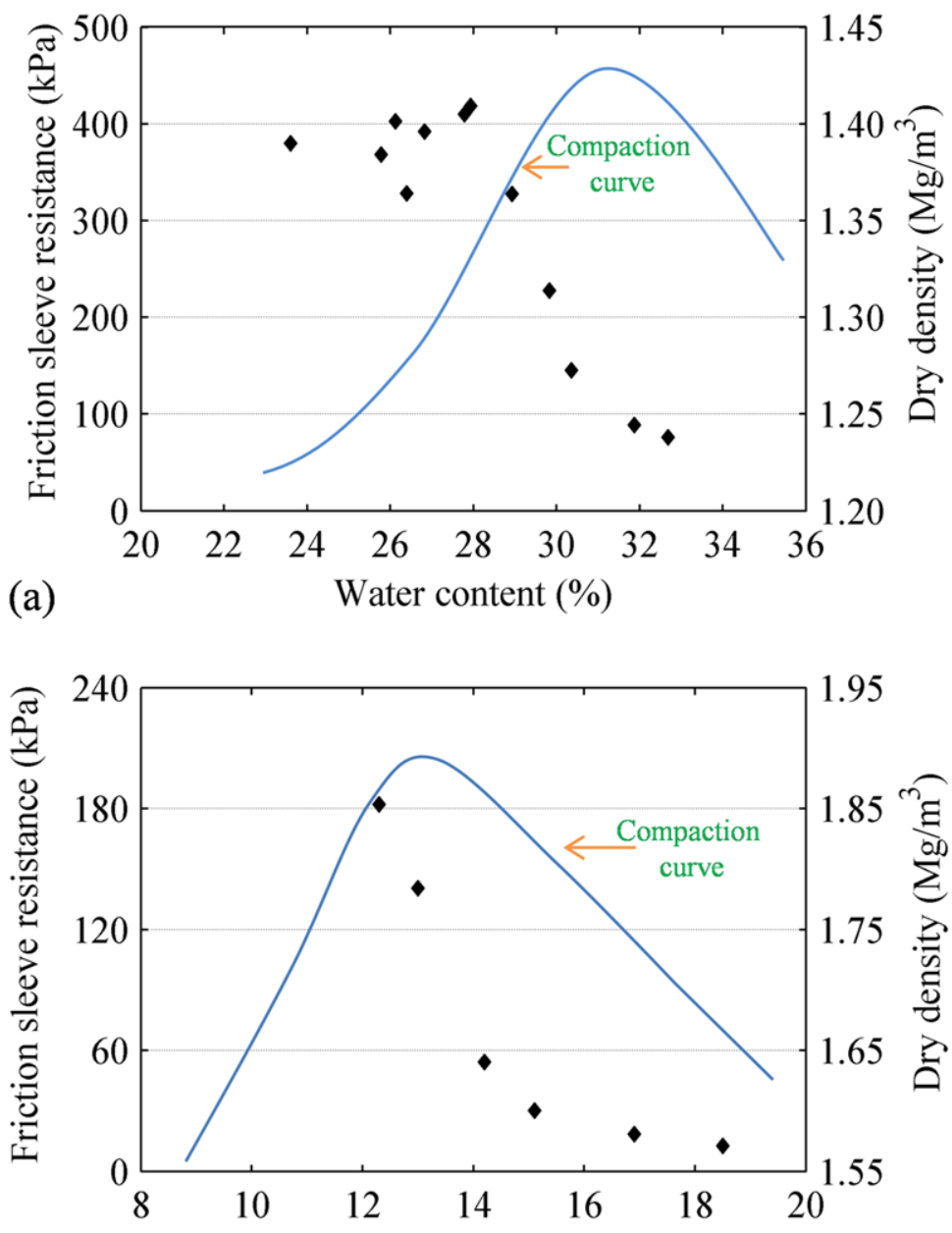

(b)

Water content (\%)

Figure 11: Friction sleeve resistances $\left(f_{s}\right)$ at different water contents and dry densities: (a) illitic material and (b) kaolinite-sand mixture. 

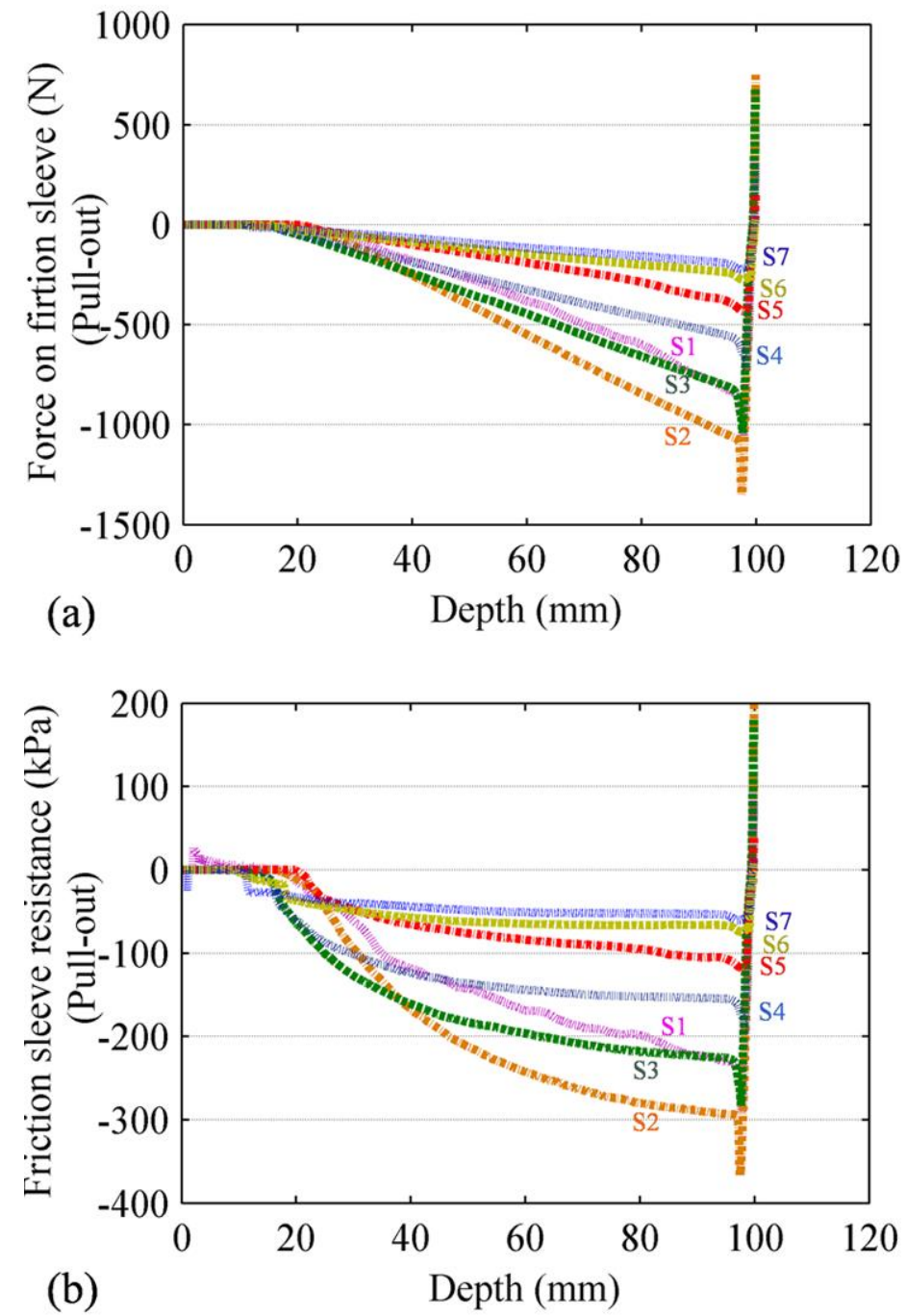

Figure 12: (a) Friction forces for samples S1 to S7 for the pull-out tests. (b) Evolution of the friction sleeve resistance $\left(f_{s}^{*}\right)$ for samples $\mathrm{S} 1$ to $\mathrm{S} 7$ for the pull-out tests. 

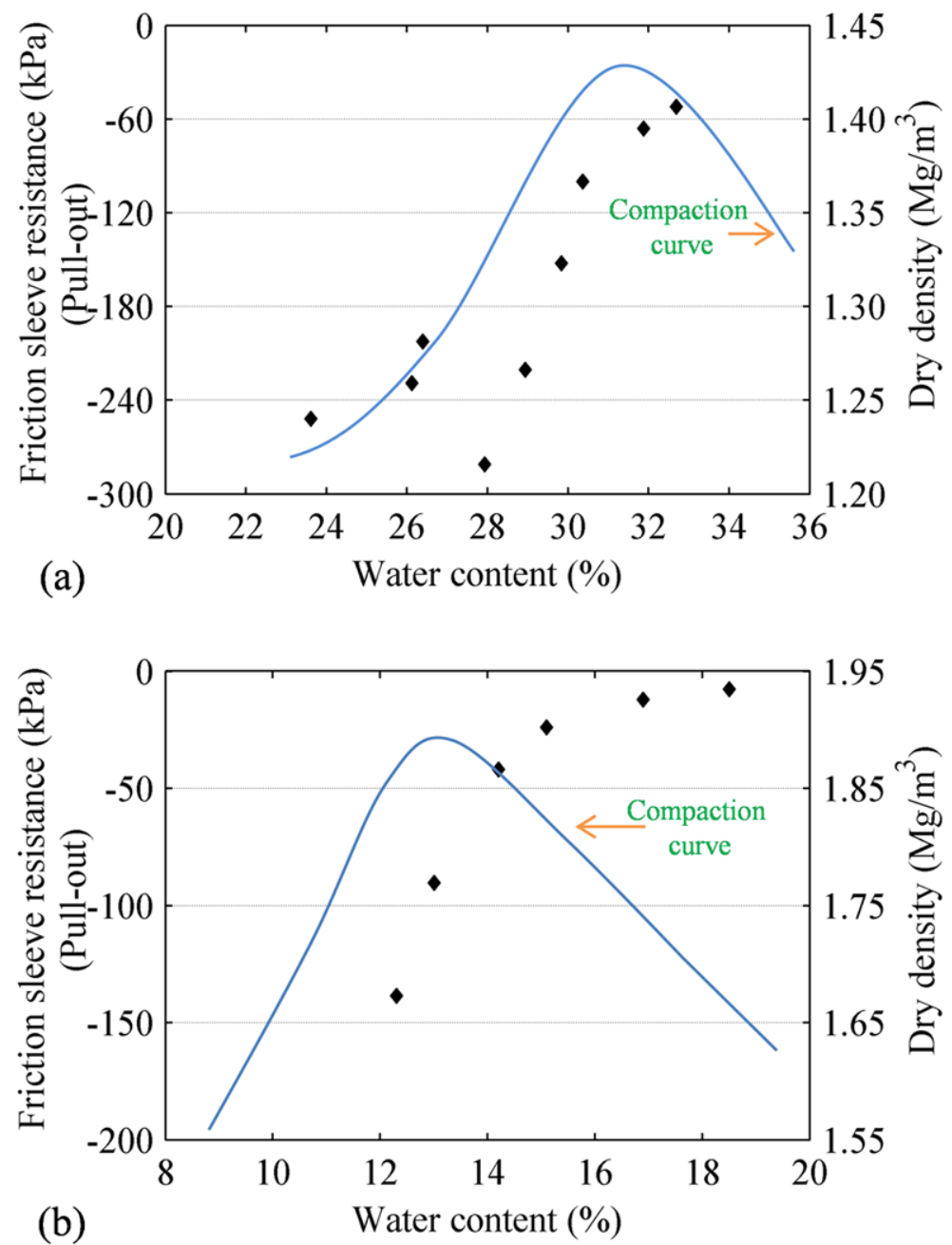

Figure 13: Mean friction sleeve resistances for the pull-out tests $\left(f_{s}^{*}\right)$ at different water contents and dry densities: (a) illitic material and (b) kaolinite-sand mixture. 

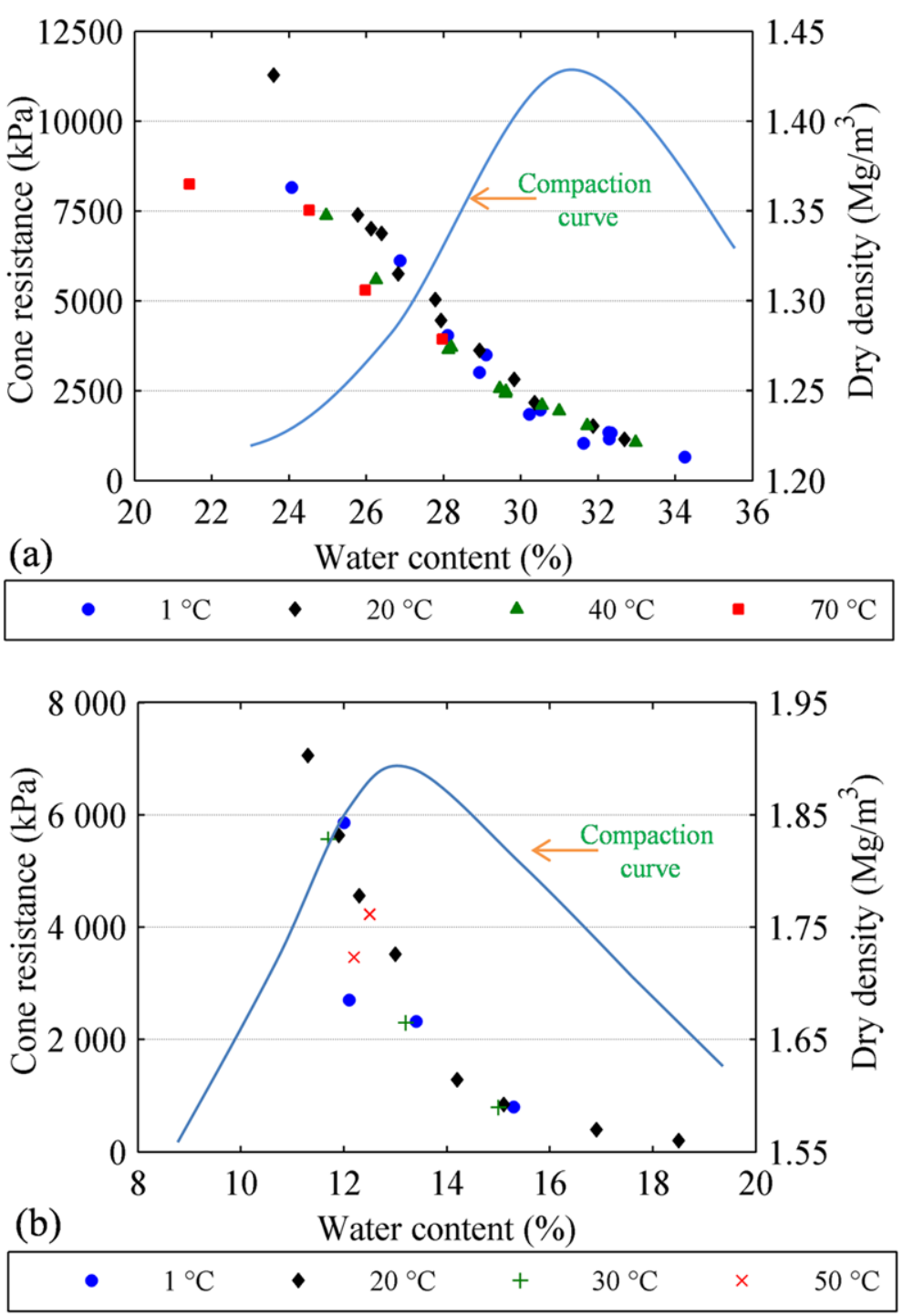

Figure 14: Mean cone tip resistances $\left(q_{c}\right)$ at different water contents and dry densities: (a) illitic material at 1, 20, 40 and $70{ }^{\circ} \mathrm{C}$ and (b) kaolinite-sand mixture at 1, 20, 30 and $50{ }^{\circ} \mathrm{C}$. 


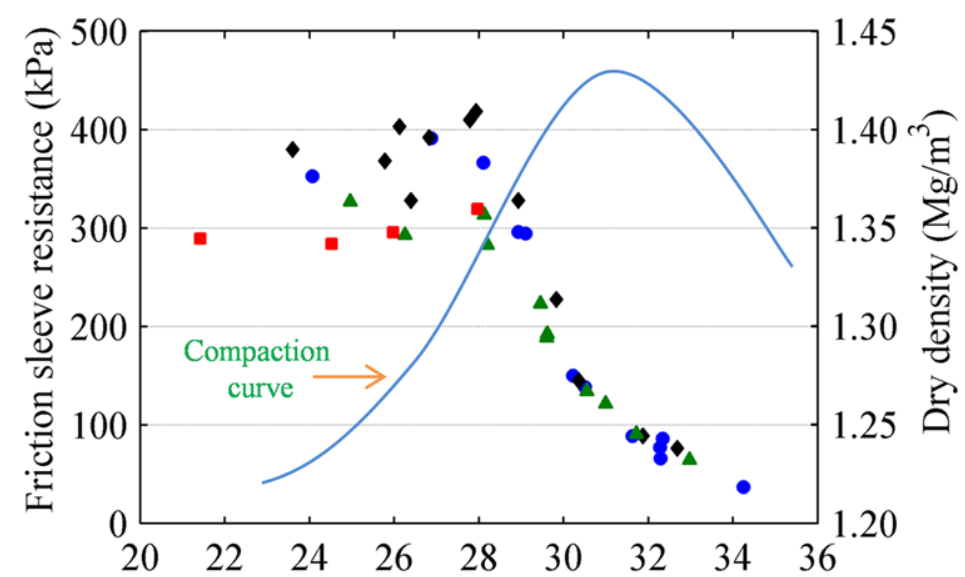

(a) Water content (\%)
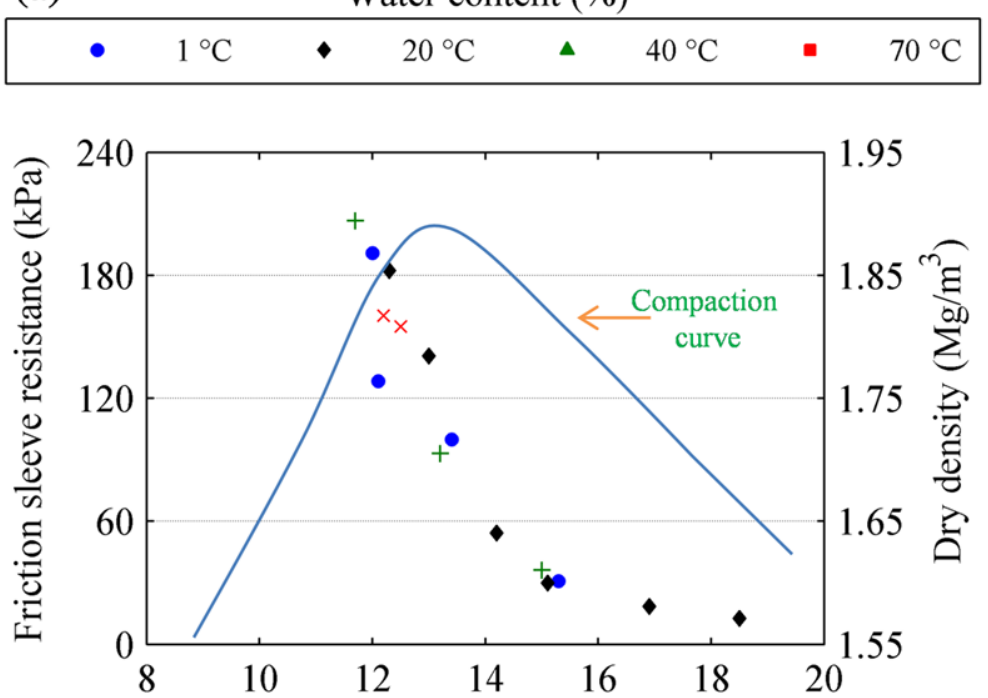

(b) Water content $(\%)$

- $1{ }^{\circ} \mathrm{C} \quad 20^{\circ} \mathrm{C}+30^{\circ} \mathrm{C} \times 50^{\circ} \mathrm{C}$

Figure 15: Mean friction sleeve resistances $\left(f_{s}\right)$ at different water contents and dry densities: (a) illitic material at 1, 20, 40 and $70{ }^{\circ} \mathrm{C}$ and (b) kaolinite-sand mixture at 1 , 20,30 and $50{ }^{\circ} \mathrm{C}$. 

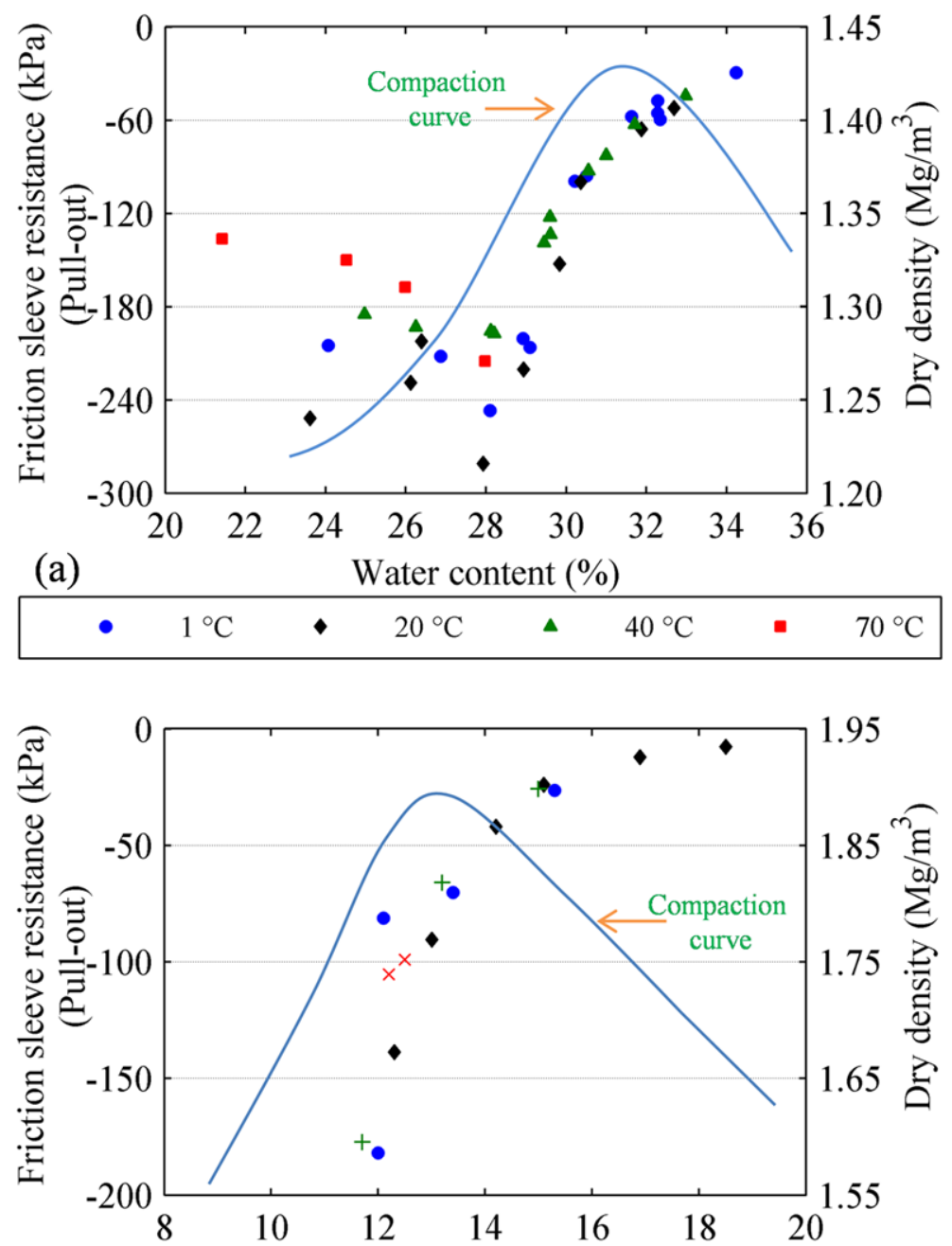

(b)

Water content $(\%)$

- $1{ }^{\circ} \mathrm{C} \quad 20{ }^{\circ} \mathrm{C}+30{ }^{\circ} \mathrm{C} \quad \times \quad 50{ }^{\circ} \mathrm{C}$

Figure 16: Mean friction sleeve resistances for the pull-out tests $\left(f_{s}^{*}\right)$ at different water contents and dry densities: (a) illitic material at $1,20,40$ and $70{ }^{\circ} \mathrm{C}$ and (b) kaolinitesand mixture at $1,20,30$ and $50{ }^{\circ} \mathrm{C}$. 